\title{
Headteachers' Instructional Leadership at Community Schools
}

\author{
Mr. Rudra Prasad Danai*
}

\begin{abstract}
This article explores instructional leadership of few headteachers of Dhading district. Due to the primitive model of school leadership, students faced obstacles in achieving educational goals. The objectives of this research are to explore the tradition of the headteachers' leadership of school and the role of the headteachers for the transformation of the educational attempts and achievements. This research followed phenomenological research method. Five headteachers leading the schools for more than a decade were interviewed. The data thus collected were interpreted through coding, categorizing and comparing the key themes. The research finds that the leadership role of the headteachers in the past was responsible for lagging behind the target of the educational achievement as recommended by the curriculum. This study concludes that the school leadership must be cross-threaded in instructional process, pedagogy, information, and communication technology (ICT).
\end{abstract}

Keywords: headteachers, instructional leadership, traditional leadership, pedagogy, educational achievement

\section{Introduction}

It was my big curiosity to understand the school headteachers and class teachers in the modern days regarding their roles in leading schools and educational practices as a leader. This question rose in my mind with seeing the bigger strides in science and technology, pedagogy in global context

* Mr. Rudra Prasad Danai is a lecturer at Adarsha Multiple Campus currently. Earlier, he was the Campus Chief. He is also a secondary English teacher and chairman of NELTA, Dhading branch.

Email: danai.rudra@gmail.com 
and research but I found the Nepalese school education achievement yet on the same paradigm of result than in other countries of Asia like China, Bhutan and India. Hence, I proposed to do an in-depth research on the instructional leadership for educational change as a new concept in the context of Nepal though this is not new to American and European country schools including the practices in China and India. I feel it necessary to do because many reports show that the secondary level education in Nepal is not qualitative despite of showered resources to the government secondary level education. According to Budhathoki et al., 2014, p. 1, "High rate of the SLC failing students from public schools shows poor quality of teachinglearning in school." Furthermore, Aryal (2013) reports that the provision of quality education has been written into government policies for more than 50 years but somewhere along the road its meaning became distorted, with quality being equated with test results, or the number of children passing the SLC by mentioning the views of undersecretary of ministry of education, Nepal. The result analysis of SLC examination from 2041 to 2050 also does not show any sign of improvement in Nepalese secondary level school education. The result percentage limits only below 50 percentages. So, in its report, GON (2005, p. 9) mentions, "Public schools and their teachers are subjected to harsh criticisms and humiliation for the persisting under-performance of students in the SLC examinations. In comparison to SAARC countries' secondary level school result also, Nepal seems below average in its result percentage. The neighboring country India, Maldives and Bhutan score approximately 70 percent whereas the SLC pass rate of Nepalese students is below 50 percent every year (GON, 2005, pp. 344345). Rijal, Poudel, Goutam, Bista, Dahal, Khatiwada, , \& Chongbang, K. B. (2017). (2017, p. 69) show:

Through the classroom observation, the teachers of the schools with low performance were found very weak in providing students with the counseling services; interacting with their colleagues about teaching learning process; planning and preparation; collecting, designing and using instructional materials; visiting the libraries; browsing internet; planning future work, and reflecting their own work.

To all these problems of raising the status of the school academically and increasing the educational achievement of the school, the headteachers' role is too important as they provides the overall leadership of school management, academic leadership and school development. Rijal et al.(2017, p. 69 ) further remark, "The roles of headteachers encompass creating an 
atmosphere of mutual cooperation among stakeholders, maintaining discipline, morale and manners, preparing schools operating plan, running daily administration, evaluating the performance of the teachers, discuss the problems of schools etc." Hence, there is a significant role of the headteacher to improve the school with outstanding performances and academic achievement as an overall leader of the school. As (Singh \& Allison, 2016, pp. 79-81) conclude visioning and goal setting, building positive school culture supporting teachers and students to improve learning, cultivating leadership in others, managing school resources and operation, leading for continuous improvement are the dimensions for effective school leadership, this research also seeks the role of headteachers for transformation of the educational attempts and achievement and the tradition of school leadership and their effect in school progress on transformative education.

\section{Literature review}

The phrase "Teacher Leadership" has multiple meanings that ranges from collective professional leadership of trade union rights to the leadership of an individual teacher to his pedagogical practices in the classroom for the psychological advancement of the learners including whole school leadership. This research mainly focuses at second type of headteachers' school leadership and his inclusive practice of planning for educational change to enhance quality in school education. The report of National Planning Commission, (2013) as cited by (Singh \& Allison, 2016, p. 2) states, "The Nepalese government's three-year interim plan for 2013-2015 clearly identified school dropout and class repetition in all grades, pointed to lower pass rates, poor quality of professional development among teachers, and lack of quality in public schools as major challenges for the immediate future. This is supposed to be burning issues in the context of Nepalese schools that the teachers are more regarded with teaching through examination point of view than helping learners learn the knowledge and skills. The Nepalese school classrooms practices are still dominated by lecture method where the learners seem to be passive and the teachers seem to be active."

The current teaching methodology focuses more on child-centered method with the use of teaching methods, research based, thought provoking, instructional technology where the students can produce or generate the knowledge by themselves. Although the teachers are aware of this, the use of modern teaching material, modern instructional technology etc., have not been used in the classroom and it has hindered on the quality in education. For 
this purpose, the headteacher and other teachers are expected to play the role of leading students to learning rather than stereotypical delivery of the lesson. I think that this would definitely make students ready to learn, get motivated, be guided, investigative, studious, interactive, practical and energized. The teacher leadership, I think, will help the teachers know their learners and make new policy of learning in their classroom. On the other hand, the overall advancement of the school environment also is in the hand of the teachers. The schools where the teachers are dynamic and leading are found to have been in the frontlines of quality in education. As cited from Cuban (1984) and Bamburg and Andrews (1990) by Hallinger, Wang, Chen, \& Li (2005),

The instructional leaders influence more than 'position power' in motivating staffs towards collective goals and these are the handson leaders, hip-deep in curriculum and instruction. They focus on coordinating, controlling and supervising curriculum and instruction as well as monitoring progress towards desired outcomes. The principals find themselves at the nexus of accountability and school improvement with an increasingly explicit expectation that they will function as 'instructional leaders' (Hallinger, 2005, p. 222).

As mentioned by Bolam (2003, 2001), Heck, personal communication (2003), Jackson (2000), Lam (2003), Leithwood (2003) and Tomlinson, (2003), in (Hallinger, 2005, p. 222), "Given the passage of formal government standards for education through the world, principals who ignore their role in monitoring and improving school performances do so at their own risk."

According to (MOE, 2016), the objectives of secondary level education are to make students ready for the world of work developing their skills and knowledge through equitable access to education without compromising on quality. This aims to provide options and accredited learning pathways for students between technical and general secondary education, strengthen institutional links and facilitate the transition to higher education, prepare students to uphold and fulfill their civic duties and ensure the acquisition of foundation skills through technical and vocational education at secondary level that will enable adolescents to acquire skill sets.

\section{Teacher as a leader}

Similarly, regarding fulfilling the demand of quality in secondary level education, claims of (Bakhati \& Ciani, 2015, p. 24)

\section{AMC Journal, Volume 2, Number 1 (2021)}


The teachers can be accepted as an effective agent to bring changes and core person of any issues in learning community. During the learning time or process, teacher is one of the trustworthy persons for students especially in the school education. One of the clear notions of every society is that if the teacher is aware of the issues associated with community or society, he can bring the positive changes because the teacher is closely connected with students, parents and community people as well.

The teachers are key role player to maintain quality in education and the headteachers are supposed to be crystal leaders to make it come true. To this point, (Dahal, 2019, p. 12) insists,

The teacher's role is very important to determine the student learning, performance and academic achievement. To this point, the headteacher is responsible to monitor the overall performance of the school including preparation of the reading materials by teachers, their punctuality in school time, teaching method, interaction with students, use of modern technology in class teaching, checking of assignment and feedback.

This proves that the pressure on schools and educational system to achieve the excellence is greater than ever before. In the case of Nepal too, there is a big pressure of the stakeholders on maintaining quality in education and the only teachers are supposed to be the players in the ring. Hence, it is necessary to explore the ways to develop teacher as the leader of education so that s/he can act to change the classroom, his school and community. In the era of globalization, the pressure on schools and educational systems to achieve excellence is greater than before. One obvious reason of emphasizing teachers' leadership and collaboration of teaching has been the core of school improvement and success. Teachers are more closely connected to student learning with front line contacts. Teachers who have excellent skills in pedagogy and who have strong willingness to help other teachers are critical for school success may offer alternative leadership forces.

As cited in Brooks, Scribner, \& Eferakorho (2004, p. 246), Fullan (1993) argued that teachers must exhibit proficiency in several "interrelated domains" to function as leaders, i.e. (1) knowledge of teaching and learning, (2) knowledge of collegiality, (3) knowledge of educational contexts, (4) knowledge through continuous learning, (5) knowledge of the change process and (6) moral purpose. 
Institute for Educational Leadership (2001) in its report has identified ten areas of teacher leadership where teacher involvement is actually essential to the health of a school (p.3). The report listed critical issues that transcend traditional roles such as instructor, evaluator, curriculum developer, and behavior manager to include promotion and retention committee member, decider of school budgets, selector of new administrators and teachers, and designer of professional development plans ("HOME | Institute for Educational Leadership," n.d.) (Brooks, 2004, p. 246).

Lieberman \& Miller (2005, p. 152) agree, "Teaching is regarded as highly intellectual work, grounded in professional communities where teachers assume responsibility for the learning of their students and of one." They interpret, "Under this interpretation, teachers assume roles as researchers, mentors, scholars, and developers; they expand the meaning of what it means to be a teacher. They are leaders and intellectuals who can make a difference in their schools and profession."

\section{Headteacher as a sole school leader}

How the teachers can address all the issues to ensure quality in education in school and increase the achievement of the students depends solely on the role of the head teacher. As mentioned in (Singh \& Allison, 2016) cited from Leithwood et al. (2008):

School leaders support teachers in order to improve their performances through building their capacities, improving working conditions, and by offering motivation to excel. Successful leaders seek to ensure their teachers have appropriate expertise by providing instructional support and the resources necessary for them to excel in their profession, providing a safe and orderly school environment, and being sensitive to the needs of individual students.

As suggested by Glanz \& Neville (1997), Hallinger \& Heck (1996) and Sheppard, (1996) cited in (Bozkuş \& Bayrak, 2019, p. 335) on the role of the headteacher in professional development of the teachers is claimed as, "School administrators play a vital role in the professional development of teachers." Similarly, as cited in (Bozkuş \& Bayrak, 2019, p. 335) from Fullan (2006), Elmore (2000), Usdan (2000) and Clement and Vandenberghe (2001), it is suggested as, "Administrators should develop the appropriate school culture to develop teachers' knowledge and skills and support teachers' professional development. In this respect, the role of administrators is to align organizational features with professional development." Brooks, Scribner 
\& Eferakorho (2004) declare, "The headteacher's role in relation to school reform and teacher leadership is crucial. Like changing conceptions of teacher leadership, headteacher leadership has also undergone a change in perspective (p. 247). They suggest two key ideas of headteacher or headteachers' role : first, successful implementation of school reform is dependent on a school's instructional capacity and second, to nurture a school's instructional capacity citing from Spillane \& Louis (2002). In a report on headteachers leadership of school, The Wallace Foundation, (2013, p. 6) recommends:

The headteacher's role entails five key responsibilities: 1) Shaping a vision of academic success for all students, one based on high standards. 2) Creating a climate hospitable to education in order that safety, a cooperative spirit and other foundations of fruitful interaction prevail. 3) Cultivating leadership in others so that teachers and other adults assume their parts in realizing the school vision. 4) Improving instruction to enable teachers to teach at their best and students to learn to their utmost. 5) Managing people, data and processes to foster school improvement.

This concludes that the headteacher as the school leader must strengthen on creating the appropriate climate of educational practices in classroom and must cultivate the vision for the best teaching and learning.

\section{Instructional leadership}

The research and reports including the articles on the leadership role of the headteacher of a school, it is focused that the headteacher's main concern is the instructional emphasis than others. He is the key responsible person in creating the hospitable teaching and learning environment, visioning and planning, shaping the instructional designs at school and influencing the teachers with innovative pedagogical attempts through motivation. (The Wallace Foundation, 2013, p. 6) envisions:

Effective work of the headteachers relentlessly is to improve achievement by focusing on the quality of instruction. They help define and promote high expectations; they attack teacher isolation and fragmented effort; and they connect directly with teachers and the classroom. Effective headteachers also encourage continual professional learning. They emphasize research-based strategies to improve teaching and learning and initiate discussions about instructional approaches, both in teams and with individual teachers. They pursue these strategies despite the preference of many teachers to be left alone. 
Here, the report finalizes that the Headteachers' work in major is to focus on quality of instructions for improving teaching. His role is supposed to be crucial for transformation of school academically with educational achievement. Geijsel, Sleegers, \& Stoel, (2009) as cited in (Shava \& Tlou., 2018, p. 4) have identified the three dimensions of transformative leadership as, "Vision development, individual consideration, and intellectual stimulation. Individual consideration has to be understood from the perspective that a transformative leader acknowledges the individual aspirations, actions, beliefs and values, rather than favouring the individual."

\section{Statement of the problem}

It is commonly believed that the quality in education reflects in the annual result of the students' grade examinations. The Secondary Education Examination (SEE) and the student success rate is assumed chiefly as the quality of education, teachers' excellence and assurance of the children's future whereas there are still many miles to go to prove the quality in education in the context of our country school. Especially in Dhading district too, among the SEE, Class 8 and 10 board examinations, the class 12-board examination result is always below fifty percent and number of failure students is bigger. Only SEE result does not prove the total quality of teachers (Department of Education (DoE), 2016, p. 70). Many stakeholders seem to be criticizing the teachers for not achieving good result. Only the teachers are supposed to be responsible keys to quality education. The government school teachers are criticized on their dedication, punctuality, competencies, skillfulness, and technical knowledge, compassion to children, updated-ness, studiousness and responsibility to the nation. The teachers are in a big moral pressure of maintaining the quality in education in reality too. This is also because the graph of private school results that seems risen very high than government schoolteachers. The comparison of private school results with that government school results not heeding to role playing factors, also creates mistrust over public school teachers and this results the decreasing number of students in rural and city-based schools. Hence, the solution over these problems must be sought in time. In nutshell, the public-school headteachers are blamed of not being able to prioritize on educational progress and seem as the leaders of school development rather than leader of educational achievement. Although he comes from teacher, his concern seems more on school management and development than quality control. 
This research will, therefore, explore the hindrances and lagging of the public-school headteachers in Nepal and suggest leadership qualities and competencies that the public-school headteachers need to build in them. As mentioned by Edmonds (1979a, 1979b, 1982) in ("Effective School Management - K.B. Everard, Geoff Morris, Ian Wilson - Google Books," n.d., p. 2), he has identified five attributes of effective schools as:

Strong administrative leadership, without which, the disparate elements of good schooling can be neither brought together nor kept together, climate of expectation in which, no children are permitted to fall below minimum but efficacious levels of achievement, the school's atmosphere is orderly without being rigid, quiet without being oppressive, and generally conducive to the instructional business at hand, make it clear that pupil acquisition of basic school skills takes precedence over all other school activities, and there must be some means by which pupil progress can be frequently monitored.

The instructional leadership behavior of the school headteachers plays crucial role on the nucleus of the school. Researches as mentioned in ("Effective School Management - K.B. Everard, Geoff Morris, Ian Wilson Google Books," n.d.) by (Larson-Knight, 2000; Blasé \& Blasé, 1999a, 1999b, 1998; Sheppard, 1996; and Chrispeels, 1992) shows that headteachers who demonstrate instructional behaviors extract more commitment and satisfaction from teachers, as well as establish a climate that encourages trust, risk, and collaboration.

In this way, such practices are widely being done in American and European School and unless, the Nepalese schoolteachers act in the same way, neither our education can grow to the height of quality nor they can win public trust.

This research is concentrated over the role and responsibilities of the public-school teachers in the current context and their expected roles for future to change their classroom, pedagogy, school and community through leader perspectives. This study explored the answers to the following questions:

i. What can be the role of the headteachers for transformation of the educational attempts and achievement?

ii. What is the tradition of headteachers leadership of school? 


\section{Rationale of the study}

The headteachers' leadership roles, such as curriculum coordinator, subject specialist, mentor and teacher trainers are considered crucial to school development due to the teacher leaders' ability to undertake major tasks, influence changes and reforms, and serve as a bridge between the top leadership and fellow teachers. Their pivotal role in school functioning has convinced educational organizations around the world to invest inleadership capacity building of teacher leaders by offering opportunities, such as PD programmes, courses and workshops. Moreover, they are encouraged to learn by taking risks, experimenting and trying new things (Bennis, 2009), by being a protégé of their senior colleagues, or working in a community of practice (Stephenson \& Howard, 2011). Teacher leaders' ability to create instructionally specific dialogues, develop trusting relationships and work in collaborative cultures lead to their professional learning Portin, (2009) as cited in (Stephenson \& Howard, 2011). These opportunities, whether selfcreated or offered by their organizations, are vital for teachers who lack educational leadership experience, training and knowledge of leadership theories and practices. Since not many studies have sought to investigate this area before, it is vital to explore how teacher leaders develop their leadership repertoire in the field of classroom, school and community.

\section{Theoretical framework}

Instructional leadership has different definitions and models that conceptualize it starting from the early 1900's. The current study synthesizes many definitions and models of instructional leadership using theoretical and empirical considerations. The instructional leadership construct is defined in terms of headteacher behavior that lead a school to educate all students to high achievement. The current research on instructional leadership incorporates behaviors, which define and communicate shared goals, monitor and provide feedback on the teaching and learning process, and promote school-wide professional development. Instructional leadership represents behaviors of a school leader. In this study, I have specifically examined the perception of secondary school headteacher. Through synthesis of different instructional leadership models according to Weber (1996), Murphy (1990), Hallinger \& Murphy (1985) and Hallinger \& Heck (1996) as mentioned in ("Effective School Management - K.B. Everard, Geoff Morris, Ian Wilson - Google Books," n.d.), I have carried out a study of an instructional leadership styles of the public school headteacher. 
(George, 2006) declares that the leadership must introduce four elements of transformational leadership, i.e., individualized consideration, Intellectual stimulation, inspirational motivation and idealized influence.

This research includes the interpretivist paradigm and interprets the leadership theory on instructional leadership for the transformation and improvisation of the schools' academic achievement through better leadership. Burns (1978, p. 4) contends in (Educational Leadership and Reform (Google eBook), 2005)Ohio State University, "The transforming leader looks for potential motives in followers, seeks to satisfy higher needs, and engages the full person of the follower." These opinions and research findings may be outstanding guidelines for instructional leadership and provide guiding vision to the headteacher.

Therefore, I have made thorough study of "theory of transformational leadership, instructional leadership of the headteachers and link it in the context of Nepalese school leadership. I also reviewed Nepalese education acts, laws including the constitutions, reviewed the research, and project reports like SSRP, SSDP, studied the educational theory, leadership theory, socio-cultural theory and elicited the core knowledge. Similarly, I surveyed the conditions of government school teachers, compared the government high schools according to their academic achievement, physical development, planning and explored the gaps.

\section{Methodology}

Nepalese public school headteachers, their leadership role and the academic status of those schools in rural area in connection with their academic achievement, students' success rate and the challenges that the school headteachers are facing to promote their school are the ontological base for this research. This research makes the interactions and interviews as the epistemological foregrounding for inquiry process. Therefore, as said, "The position of interpretivism in relation to ontology and epistemology is that interpretivist believe the reality is multiple and relative," mentioned by Hudson and Ozanne, (1988) in (Bagozzi, 1991, p. 508), this research has adopted interpretivist paradigm to explain, as recommended by (Guba \& Lincoln, 1995), that these multiple realities also depend on other systems for meanings, which make it even more difficult to interpret in terms of fixed realities. The knowledge acquired in this discipline is socially constructed rather than objectively determined (Carson, Gilmore, Perry, \& Gronhaug, 2011). According to (Dammak, n.d.), "Epistemologically, interpretivist 
adhere to a subjectivist view in those subjective meanings and subjective interpretations have great importance. Like suggested by (Dammak, n.d.) "Interpretive researchers use different methodologies such as case studies, phenomenology, and ethnography, this research has followed the phenomenological design. As cited by (Dammak, n.d.) from Denzin and Lincoln (2008: 29), "Qualitative researchers deploy a wide range of interconnected interpretive methods, always seeking better ways to make more understandable the worlds of experiences they have studied" and according to (Sönmez, 2013), "The philosophical base of interpretive research is hermeneutics and phenomenology (Boland, 1985). This research too is based on phenomenological model and has followed qualitative, descriptive design. I gathered information/ data from the target population, analyzed and presented collected data by implementing an in-depth research design to provide insights into the why and how of research.

The participants for this research were sampled on the basis of purposive judgmental sampling. Five public secondary school headteachers were selected and interviewed with open-ended questions, unstructured interview schedule. Some published data also were taken for determining the questionnaire and interview. The data analysis in this research is based on description. This method involves the reformulation of stories presented by participants taking into account context of each case and different experiences of each participant. In other words, narrative analysis is the revision of primary qualitative data by researcher. Therefore, I have described the story of both groups of participants, show the comparisons and make conclusions.

A research is not only a scientific, investigative process but also an ethical process. A researcher has to assure and ensure there will be no any sort of harm, insecurity, lose, confidentiality and selfish treatment to the participants by the researcher. Hence, I abided by the civil rights of the citizens with respect to the rights of security, secrecy, safety and have regarded my participant only as the primary source of data. The data have not been interpreted by mentioning the participant name third person point of view has been used.

This research has covered only within the headteacher's' practices of classroom teaching planning and leading schools with better exercise. This is the study of only the role of headteachers in leading schools according to the result percentage of the students in board examinations and promotions of the school's physical development and planning. This will be only the 
study of public high schools of the southern two village municipality schools.

\section{Result and discussion}

In the 20-minute-long interview of the school leaders, i.e., head-teachers as the participant of this research, one of them responded that he was the founding headteacher of the school in the remote part of the district and he was administering the school for the last 30 years and he also has been leading teachers' professional organization. Another participant replied that he had run a private school for the last ten years as the headteacher and later after succeeding in Teacher Service Commission's examination of secondary level; he began teaching English and later has been assigned the responsibility of the headteacher for the last year. Before being the headteacher, he replied that he worked as the assistant headteacher of the school. The other three research participants were experienced head teacher running public school for a decade. This shows that the participants were experienced school leaders.

\section{Status of educational outcome}

All the participants' schools were well established high school in Dhading. Their response to a question asked on the status of academic achievement was that their school had satisfactory result as an educational achievement in comparison to the past time and current neighboring schools but that was not commendable in comparison to the district average. According to Mathema (2007) as cited by (Parajuli \& Das, 2013, p. 151) "Nepal is confronted with two major problems- firstly a great number of youth are still out of school and secondly a great majority of those who are in school are not receiving quality education." The participant agreed that the school's academic outcome in the past was very poor due to lack of trained and qualified teachers, learner friendly infrastructure and traditional approach of the leadership of the headteacher. They claimed that this is improving nowadays with the availability of the good, qualified and trained teachers including building of infrastructures

\section{Leadership types}

The instructional process in the school is the key factor in school's educational achievement. The teachers are the key role players of theclassroom instruction and the headteacher is the sole leader of the instructional process, integration of technology with methodology for overall instructional system of the 
school. In case the headteachers cannot attend on these matters, the classroom instruction that can directly affect the school's educational achievement can be unstructured, unsystematic and cannot achieve the goals. A school headteacher is the one who plays crucial role in unifying the instructional process at school within certain frame. Hence, the school progress or the learner's achievement depends on the role of the school leaders. Lynch (2016) suggests, "There are four types of leadership playing different roles and according to the strategy they work including their effect in academia, i.e., servant leadership, transactional leadership, emotional leadership and transformational leadership. On this matter, the participants' view was that the cause of most of the school's failure was chiefly the primitive approach of school leadership. The leadership in the primitive approach was that he was autocratic with some power of bureaucracy in the initial phase, the autocratic leader in the past possessed terrific personality and maintained hierarchy of their positions and respect. This kept the distance between the teacher and students and limited the teaching and learning into the formality rather than nurturing learning habit. In the medieval period of Nepal i.e. before the sixties in the context of Nepal, the headteacher became like a manager who had to manage every environment of the school and had less attention on the instructional functions. The managerial headteachers' job was just to manage the learning environment where the students are sought to learn by themselves and teaching and learning more focused on developing cognitive constructivism. The participants viewed that the current time is the time of technology which has burst the knowledge in the world and also has networked the world teachers and learners. Hence, the headteachers of schools have new challenge of adjusting themselves, their school culture and stakeholders to the instructional process. This is also because, the school teachers and headteachers nowadays, come from the sound academic environment bringing more academic excellence than the previous school leaders. The instructional headteacher is that school leader who envisions the school with prediction of target to achieve for future and they emphasize on social construction of knowledge. He accepts the facts that the knowledge is generated as a result of collaboration between teachers and students. On this regard, the instructional leaders as the headteachers of school vision and act together, make their educational activities inclusive from all angles, and keep information of educational innovation in global perspective, plan and implicate in their schools for good result and learning. This concludes that there are three types of school headteacher i.e., a) Autocratic b) Managerial and c) Instructional. The autocratic and managerial headteachers have many problems in running 
schools that causes the educational underachievement. The autocratic headteacher is hierarchical, bossy and power imposing. The managerial headteacher engages more in management than in leading school with educational, learning oriented activities and he is far off the pedagogy. He is procedural, legal and works as a resource person. The best of the school headteachers are those who can provide instructional leadership like the transformative leaders as suggested by Lynch (2016) to the school with technology, pedagogy and collaboration. The instructional leadership is the most wanted demand of the stakeholders in running schools otherwise the school lags behind the target always.

\section{Challenges in instructional leadership}

Instructional leadership is the latest concept of the leadership as a reaction to the problems created by the autocratic and managerial leadership of the headteacher in school to fulfill the academic achievement in the ground. Since, it came as the reaction to the former two leadership process, it has big challenges of maintaining quality in school result, academic excellence and creating the proper instructional environment between the student and teachers. As said by Timperley(2005, pp. 16-17), the challenges for instructional leadership at school are, "Developing systems for promoting professional learning, improving the capacity of individuals and school, contextualizing the learning within the teachers' actual work situations, and transferring of skills and knowledge from the learning environment to the classroom and enthusiasm for developing internal capacity." The centre of focus of this kind of leadership is to play vital role in pedagogy and technological integration, keeping information of everything as the leader and addressing all kinds of educational problems. Updating own-self including the colleagues, changing the classroom procedure, maintaining collaboration and participation, visioning for future achievement and academic excellence and giving distinct identity of the school than the past are the challenges of instructional leadership. Unless a paradigm shift on pedagogical practices and establishing quality circle for quality product in school, the learners cannot learn competitively and cannot be ready for global opportunity.

\section{Defects of primitive leadership}

The history of school leadership from the past is the most responsible unit to the progress and failure of the school. The bossy headteachers autocratic with the bureaucratic power were more concerned on the legal process 
and their dignity rather than on quality of school. Only the education was for enthusiasts and most of the learners did not catch the target. Hence, it showed the performance of the school very poor. To improve the situation, new type of leadership was imagined and created as the managerial headteacher who focused only on construction of the environment rather than construction of the knowledge. Both of the school leaders were unable to meet the educational target. During these leadership period, especially teaching and learning based on examination-oriented training and the number of the students having pass result were accounted as the educational successfulness. The learners were more imposed to learning through listening and reading. Teachers' stereotypical delivery of the lesson was the major factor during that period. The student's potential of learning and their creativity as well as knowledge were not prioritized. The things aimed at teaching were not taught very well and it did not discriminate the personality of the educated with uneducated.

\section{Schools with instructional leadership}

The schools with instructional leadership emphasize on pedagogical shift. The schools must be established as the resource centre for knowledge whereabout the students keep trust as they can solve their problems by going there. They must be assured that they can get enough support from their teachers and standardize their knowledge and skills as per global perspectives. These schools are not for rote learning. Instead, they must be able to collapse the barrier that limits the learning. This must be able to show the guidelines for future of the students. Wallace Foundation (2012, p. 4) suggests, "Shaping a vision of academic success for all students, creating a climate hospitable to education, cultivating leadership in others, improving instruction, managing people, data and processes to foster school improvement." The schools with instructional leadership must maintain the learning environment through future vision, instructional improvements and appropriate learning environment everywhere and widen the universality of the learning.

\section{Conclusions}

This research on instructional leadership is the outcome of the dissatisfaction to the traditional schooling system. This came as a result of the pursuit of alternatives to traditional schooling system and explored many possibilities of changing the schools with better learning and cash the competitive educational achievement. This concludes that the children today are seeking instructional leadership of the school headteacher which can line up for 
pedagogy, honour learner creation, flexibility of instructors, updating of the teachers, maintaining collaboration and cooperation and let the potential of the learners burst out in the classroom.

In Nutshell, due to predominance of autocratic primitive leaders of the school as the headteachers in the past, quality in education could not be maintained in our context. Similarly, the medieval period school leaders too were failure character due to their managerial role and never paid attention to the school pedagogy, staff motivation, collaboration, discuss on agenda of quality and success of the learners. A school, if cannot play crucial role on shaping the children's mind, is no longer a better place for them. Hence, the instructional leaders only can address all those issues and establish the school as the best learning place which can shape the children's future through quality in education and creates the environment. The headteachers in the present context rise to this situation for the overall improvement of quality in education at school.

\section{References}

Aryal, M. (2013). Nepal scores low on quality education. Retrieved from Inter Press Service, News Agency website: http://www.ipsnews.net/2013/07/nepal-scores-low-onquality-education/

Bagozzi, R. P. (1991). Principle of consumer research. Journal of Consumer Research, 17(March), 508-521.

Bakhati, A. \& Ciani, A. (2015). Promoting education for sustainable development at the University of Prishtina, Kosovo. 1(1), 139-151. https://doi.org/10.1007/978-3-319-09474-8_11

Bozkuş, K. \& Bayrak, C. (2019). The application of the dynamic teacher professional development through experimental action research. International Electronic Journal of Elementary Education, 11(4), 335-352. https:/ / doi.org/10.26822/iejee.2019450792

Brooks, J. S., Scribner, J. P. \& Eferakorho, J. (2004). Teacher leadership in the context of whole school reform. Journal of School Leadership, 14(3), 242-265. https://doi. org/10.1177/105268460401400301

Budhathoki, C. B., Khatri, H. B., Shrestha, D., Rana, B. K., Sigdel, T. P., Panta, K. \& Thapa, S. W. (2014). Status of SLC dropouts and identifying ways to engaging students in cocurricular activities. (Ed. David Hayes). Kathmandu: British Council.

Carson, D., Gilmore, A., Perry C., \& Gronhaug, K. (2011). Qualitative marketing research. In https://doi.org/10.4135/9781849209625

Dahal, T. P. (2019). Role of teacher in enhancing quality education of secondary level public school of Nepal. Journal of Multidisciplinary Research ( NJMR ) ISSN : 2645-8470 September 2019. 2(3), 9-13. 
Department of Education (DoE) (2016). Status Report 2015/016. 261. Sanothimi, Bhaktapur: Department of Education Monitoring \& Management Section.

Educational Leadership and Reform (Google eBook) (p. 347) (2005). Retrieved from http:/ / books. google.com/books?id=SsdXT9Dy8o4C\&pgis=1

EffectiveSchool Management-K.B. Everard, Geoff Morris, Ian Wilson-Google Books. (n.d.). Retrieved 15, March, 2020, from https:/ / books.google.com.np/books?hl=en\&lr=\&id $=J X d j S 744 \mathrm{~N} 2 \mathrm{cC} \& o \mathrm{i}=$ fnd $\& \mathrm{pg}=\mathrm{PR} 9 \& \mathrm{dq}=$ school+management + principles\&ots $=3 \mathrm{Ky}$ cO561Po\&sig=ep63g8uR07hBc3E3o3c7PJ5-Ixk\&redir_esc=y\#v=onepage\&q=school management principles\& $\mathrm{f}=$ false

George, W. (2006). Transformational leadership. Enterprise Transformation: Understanding and Enabling Fundamental Change, 69-77. https:/ / doi.org/10.1002/0470007826.ch4

Guba, E. G. \& Lincoln, Y. S. (2005). Paradigmatic controversies, contradictions, and emerging confluences. In N. K. Denzin \& Y. S. Lincoln (Eds.), The Sage Handbook of Qualitative Research (p. 191-215). Sage Publications Ltd.

Hallinger, P. (2005). Instructional leadership and the school principal: A passing fancy that refuses to fade away. Leadership and Policy in Schools, 4(3), 221-239. https://doi. org/10.1080/15700760500244793

Hallinger, P., Wang, W. C., Chen, C. W. \& Li, D. (2015). Assessing instructional leadership with the principal instructional management rating scale. In Assessing Instructional Leadership with the Principal Instructional Management Rating Scale. https://doi. org/10.1007/978-3-319-15533-3

HOME | Institute for Educational Leadership. (n.d.). Retrieved February 27, 2021, from https://iel.org/

Lieberman, A., \& Miller, L. (2005). Teachers as leaders. Educational Forum, 69(2), 151-162. https://doi.org/10.1080/00131720508984679

Lynch, M. (2016). 4 Major types of educational leadership. Retrieved July 10, 2020, from The Advocate Website: https://www.theedadvocate.org/4-major-types-of-educationalleadership/ of Nepal.

Parajuli, D. R. \& Das, T. (2013). Performance of community schools in Nepal: A macro level analysis. International Journal of Scientific \& Technology Research, 2(7), 148-154.

Rijal, R., Poudel, N., Goutam, S., Bista, S. K., Dahal, D., Khatiwada, T. \& Chongbang, K. B. (2017). A study on factors of student learning achievements and dynamics for better learning conditions: A case study focused to grade five in some selected schools. Kathmandu: Rural Development Society \& Molung Foundation.

Shava, G. N., \& Tlou., F. N. (2018). Principal leadership and school improvement: Experiences from south african school contexts. International Journal of Innovative and Applied Research, $x x-x x$ Vol. 4. Retrieved from http://www.journalijiar.com

Singh, S. B. \& Allison, D. J. (2016). School leadership practices of headteachers in Kathmandu. The Research Gate, 44(3), 75-93. Retrieved from https://www. researchgate.net/publication/328052151\%0ASchool 
Sönmez, A. (2013). Research methodology and design. Contributions to Management Science, 63-112. https://doi.org/10.1007/978-3-319-02033-4_3

Timperley, H. S. (2005). Instructional leadership challenges: The case of using student achievement information for instructional improvement. Leadership and Policy in Schools, 4(1), 3-22. https:// doi.org/10.1080/15700760590924591

Wallace Foundation (2012). The school principal as leader: guiding schools to better teaching and learning. (January). Retrieved from http://www.wallacefoundation.org/knowledgecenter/school-leadership/effective-principal-leadership/Documents/The-SchoolPrincipal-as-Leader-Guiding-Schools-to-Better-Teaching-and-Learning.pdf

Wallace Foundation (2013). The school principal as a leader: Guiding schools - wallace foundation. $11^{\text {th }}$ January, 41-56. Retrieved from http:// www.wallacefoundation.org/knowledgecenter/pages/the-school-principal-as-leader-guiding-schools-to-better-teachingand-learning.aspx 